\title{
Caregiving: The Odyssey of Becoming More Human
}

\section{Citation}

Kleinman, Arthur. 2009. Caregiving: The odyssey of becoming more human. The Lancet 373(9660): 292-293.

\section{Published Version}

http://dx.doi.org/10.1016/S0140-6736(09)60087-8

\section{Permanent link}

http://nrs.harvard.edu/urn-3:HUL.InstRepos:2757542

\section{Terms of Use}

This article was downloaded from Harvard University's DASH repository, and is made available under the terms and conditions applicable to Open Access Policy Articles, as set forth at http:// nrs.harvard.edu/urn-3:HUL.InstRepos:dash.current.terms-of-use\#OAP

\section{Share Your Story}

The Harvard community has made this article openly available.

Please share how this access benefits you. Submit a story.

Accessibility 
The Lancet, in press January 2009

\title{
The art of medicine \\ Caregiving: the odyssey of becoming more human
}

\author{
"Let the more loving one be me." \\ W H Auden, The More Loving One
}

I lead her across the living room, holding her hand behind my back, so that I can navigate the two of us between chairs, sofas, end tables, over Persian rugs, through the passageway and into the kitchen. I help her find and carefully place herself in a chair, one of four at the oval-shaped oak table. She turns the wrong way, forcing the chair outward; I push her legs around and in, under the table's edge. The sun streams through the bank of windows. The brightness of the light and its warmth, on an otherwise freezing winter's day, make her smile. She turns toward me. The uneven pupils in Joan Kleinman's greenbrown eyes look above and beyond my head, searching acutely for my face. Gently I turn her head towards me. I grin broadly as she raises her eyebrows in recognition, shakes her long brown hair and the soft warmth of her sudden happiness lights up her still strikingly beautiful face. "Wonderful!" she whispers. "I'm a Palo Alto, a California girl. I like it warm."

I place a fork in her right hand and guide it to the poached egg in the deep bowl. I have already cut up the toast, so that I can help her spear pieces of bread and soak up the yolk. She can't find the tea cup in front of her, so I move her hand next to its handle. The Darjeeling tea glows hot and golden red in the Chinese tea cup. "Wonderful!" she again whispers.

Later, while I am trying to decide what she should wear, Joan frowns, fussing with her feet. "These nails are too long. And where are my shoes? I need to find my shoes?" She stands before about 18 pairs on a rack, shoes her unseeing brain can't recognise. "Don't get agitated," I interject with foreboding. "Do you want a Zyprexa?"

"No! No pills. Why do I need pills. I'm healthy."

“Joan, you have Alzheimer's disease. You're not healthy. You have a brain disease. A serious problem." I can barely conceal the frustration in my voice.

"Why did God do this to me? I've always been good. I never did anything to cause this. Should I kill myself?" She says it in such a way as to signal to me, as she has before, that 
this is a statement of pain and a cry for help, not an earnest question to discuss or to make plans. In fact it means the opposite: because, as in the past, she quickly changes tone. "If you love then you can do it! We can live and love."

"We can do it" I repeat, each time a little bit more weakly, enduring the unendurable.

And so, another morning begins, another day of caregiving and care-receiving between a 67-year-old man and a 69-year-old woman who have lived together passionately and collaboratively for 43 years, absorbed in an intense relationship -intellectual, aesthetic, sexual, emotional, moral. What has made it possible to get even this far are our two adult children, their spouses, my 95-year-old mother, my brother, and our four grandchildren who sometimes take the hand of their often uncomprehending grandmother, because she is standing alone, lost, and lead her back into the protective, enabling circle of our family.

For 5 years we have lived through and found ways to manage the progressive neurodegenerative disorder that has unspooled the neural networks of Joan's brain. It originated in the occipital lobes at the far back of the brain. The pathology of undoing has inexorably worked its way forward to the parietal and temporal lobes on the sides of the brain, and finally to the frontal lobes that mount up behind the forehead, through the layers of neurons and nodes of connecting neural nets that structure and retain memories, focus attention, balance emotion with common sense, underwrite judgment, and make possible the ordinariness of reading, writing, telling stories, understanding jokes, recognising people, orienting oneself in space and in time, but also within emotional and moral coordinates, and, of course, doing things in the world.

This trail of unravelled brain structure and mounting dysfunction is, in physical terms, only one of inches; yet, its silent, implacable wrecking creates entirely new conditions for living a life and being with others. Joan has an atypical form of Alzheimer's disease that perhaps only $5 \%$ of patients experience. She is, as I write, functionally blind. She cannot find her way in our home, where she has lived since 1982. She often misinterprets those objects she does see, treating a chair as if it were a table, the car a tree, the floor lamp a person. Left unaccompanied, she walks into doors and has banged her legs so hard into low tables she didn't see that she has caused deep contusions. Once, at our son's house, she opened a door and fell down a flight of unseen stairs, breaking her pelvis; at the onset of the disease, she ran into the street, where a pick-up truck ran over her right foot.

Joan can't, on her own, find her way out of the bedroom. Yet, once safely in my hands or those of our trusted home health aide, she can walk effectively. A China scholar who translates and interprets ancient texts, she can no longer read. A wife and mother whose fierce commitment to the family was its moral backbone, she now struggles to be part of family functions and can sometimes seem impassive and cut off in the midst of her children and grandchildren. Formerly the primary caregiver for her husband and children, she is now the care-receiver. She may no longer be who she was even 5 years ago, but her 
subjectivity has not so much disappeared - there is much of her personality that is still present - as altered. And that alteration has affected what had been for four decades an all consuming relationship - our identity and orientation. I still cannot accept to treat her as if she can no longer share the sensibility and narrative we have created over four decades, and yet, more and more frequently she can't. She is happy much of the time. It is me, the caregiver, who, more often, is sad and despairing.

She is a source of great concern to each of us, her family members, about how to best manage her condition. We grieve what we have lost and fear what we know lies ahead. We have each of us gone through feelings of loss, anger, and frustration. We have been marked by a special kind of pain. But we have also experienced a deepening sense of responsibility, gratitude for all that we had lived through together, love, solidarity, and a shared sensibility that we have resisted what is beyond our control and are, individually and collectively, more for it. This is not meant as a self-satisfying summing up-there is no final summary yet and the proper genre is tragedy, as millions who are engaged in these everyday practices know.

I am writing principally about people like me who give care to loved ones who suffer the infirmities of advanced age, serious disabilities, terminal illnesses, and the devastating consequences of health catastrophes like stroke or a major accident or dementia. Faced with these crises, family and close friends become responsible for assistance with all the practical, mundane activities of daily living: dressing, feeding, bathing, toileting, ambulating, communicating, and interfacing with the health-care system. Caregivers protect the vulnerable and dependent. To use the experience-distorting technical language: they offer cognitive, behavioural, and emotional support. And because caregiving is so tiring, and emotionally draining, effective caregiving requires that the caregivers themselves regularly receive practical and emotional support.

But, to use the close experiential language of actually doing it, caregiving is also a defining moral practice. It is a practice of empathic imagination, responsibility, witnessing, and solidarity with those in great need. It is a moral practice that makes caregivers, and at times even the care-receivers, more present and thereby fully human. If the ancient Chinese perception is right that we are not born fully human, but only become so as we cultivate ourselves and our relations with others - and that we must do so in a threatening world where things often go terribly wrong and where what we are able to control is very limited - then caregiving is one of those relationships and practices of self-cultivation that make us, even as we experience our limits and failures, more human. It completes (not absolutely, but as a kind of burnishing of what we really are-warts and all) our humanity. And if that Chinese perspective is also right (as I believe it is), when it claims that by building our humanity, we humanise the world, then our own ethical cultivation at the very least fosters that of others and holds the potential, through those relationships, of deepening meaning, beauty, and goodness in our experience of the world. 
I am not a naive moralist. I've had far too much experience of the demands, tensions, and downright failures of caregiving to fall into sentimentality and utopianism. Caregiving is not easy. It consumes time, energy, and financial resources. It sucks out strength and determination. It turns simple ideas of efficacy and hope into big question marks. It can amplify anguish and desperation. It can divide the self. It can bring out family conflicts. It can separate out those who care from those who can't or won't handle it. It is very difficult. It is also far more complex, uncertain, and unbounded than professional medical and nursing models suggest. I know about the moral core of caregiving not nearly so much from my professional life as a psychiatrist and medical anthropologist, nor principally from the research literature and my own studies, but primarily because of my new life of practice as the primary caregiver for Joan Kleinman.

I learned to be a caregiver by doing it, because I had to do it; it was there to do. I think this is how most people learn to be caregivers, for the elderly, the disabled, the chronically ill, the terminal. But of course this is also how parents, especially mothers, learn to care for children. My point is not so dissimilar to what William James claimed was how we learn to feel emotions: we move, we respond, we act. Our muscles (voluntary and involuntary) move. And so out of practices comes affect. And out of practices comes caregiving. We are caregivers because we practise caregiving. It is all the little concrete things I described in caring for my wife that taken together and over time constitute my caregiving, that make me a caregiver. So much depends on those concrete things: the doing, the feeling, the shadings, the symphonic complexity, the inadequacy, the living at every moment and over what can be such a long journey of the incompleteness yet the presence of a caregiver.

Arthur Kleinman

Harvard Medical School, Cambridge, MA 02138, USA

kleinman@wjh.harvard.edu 